\title{
Andreas Albertsen*
}

\section{The Luck Egalitarianism of G.A. Cohen - A Reply to David Miller}

DOI 10.1515/sats-2017-0008

Abstract: The late G.A. Cohen is routinely considered a founding father of luck egalitarianism, a prominent responsibility-sensitive theory of distributive justice. David Miller argues that Cohen's considered beliefs on distributive justice are not best understood as luck egalitarian. While the relationship between distributive justice and personal responsibility plays an important part in Cohen's work, Miller maintains that it should be considered an isolated theme confined to Cohen's exchange with Dworkin. We should not understand the view Cohen defends in this exchange as Cohen's considered view. Accepting this thesis would change both our understanding of Cohen's political philosophy and many recent luck egalitarian contributions. Miller's argument offers an opportunity to reassess Cohen's writings as a whole. Ultimately, however, the textual evidence against Miller's argument is overwhelming. Cohen clearly considers the exchange with Dworkin to be about egalitarianism as such rather than about the best responsibility-sensitive version of egalitarianism. Furthermore, Cohen often offers luck egalitarian formulations of his own view outside of the exchange with Dworkin and uses luck egalitarianism as an independent yardstick for evaluating principles and distributions.

\section{Introduction}

In recent decades, luck egalitarianism has become an influential theory of distributive justice. As a responsibility-sensitive theory, luck egalitarianism seeks to combine egalitarian notions with sentiments of personal responsibility. It is often summarized in Temkin's words as being 'bad - unjust and unfair - for some to be worse off than others through no fault or choice of their own' (L. Temkin, 1993, 13). ${ }^{1}$ Scholars routinely list the late G.A. Cohen as one of the

1 The genesis of this canonical formulation is interesting. In his $\mathrm{PhD}$ on inequality and his later article 'Inequality', Temkin's formulation addressed only 'fault' and thus not 'choice' (L.S.

*Corresponding author: Andreas Albertsen, Aarhus Universitet, Department of Political Science, Aarhus, Denmark, E-mail: aba@ps.au.dk

http://orcid.org/0000-0001-7528-2493 
founding fathers of luck egalitarianism ${ }^{2}$ and discuss his writings as an important contribution to this line of thought. ${ }^{3}$ In a very interesting recent contribution, David Miller has argued that Cohen was not a luck egalitarian after all. Specifically, Miller argues that Cohen's own considered view on distributive justice should not be considered luck egalitarian. This article sets out to assess that claim in a discussion of importance to both our understanding of Cohen's work and luck egalitarianism as such.

Cohen's early work focused on the Marxist theory of history ${ }^{4}$ and was integral to the formation of the tradition now known as analytical Marxism. ${ }^{5}$ However, a change of emphasis meant that he took up issues regarding distributive justice (G.A. Cohen, 1995b, 7; 2001a, 101-115). ${ }^{6}$ In 30 years of writing about distributive justice, Cohen offered important criticisms of some of the most prominent contemporary positions: Nozick, Dworkin and Rawls. Against Nozick, Cohen (1995b) argued that that state redistribution does not infringe on selfownership and freedom. Against Dworkin, Cohen $(1989,1993,2004)$ argues that welfare is a concern for distributive justice and that Dworkin's equality of resources fails to capture adequately how personal responsibility matters for distributive justice. Against Rawls, Cohen (2001a, 2008) takes to task one of the common interpretations of Rawls difference principle, namely its ability to justify economic incentives for the talented. In effect, Miller argues that Cohen's exchange with Dworkin did not reflect Cohen's considered belief

Temkin, 1986, 101). Cohen thought fault to mean 'moral fault' and therefore chose to add choices in his 'On the Currency of Egalitarian Justice' (2009a, 20 n20). Temkin reveals that he originally had such a broad understanding of fault in mind (L. Temkin, 2013, 25 n3) and therefore on later occasions used a formulation encompassing both fault and choice. Unsurprisingly, we can identify many formulations in the luck egalitarian literature leaning towards or explicitly citing Temkin's formulation (Arneson, 1989, 85, 2000; G.A. Cohen, 1989, 916; J.E. Roemer, 1996a, 179-180).

2 For a non-exhaustive list of such presentations, see Arneson (2011), Knight (2009b, 2013), Knight and Stemplowska (2011), Lippert-Rasmussen (2015), J.E. Roemer (1996b) and J.E. Roemer (1993).

3 For such discussion, see Albertsen and Midtgaard (2014), Arneson (2011), Heath (2008), Kaufman (2014), Knight (2009b; 2013), Knight and Stemplowska (2011), Lippert-Rasmussen (2001; 2009; 2013), J.E. Roemer (1993, 1995), Segall (2007, 2010, 2013, 2016), Stemplowska (2013), L. Temkin (2011), Thaysen and Albertsen (2017).

4 See G.A. Cohen (1978; 1988). For an illuminating overview of Cohen's views regarding both Marx and political philosophy, see G.A. Cohen (2013b).

5 G.A. Cohen (2000, x), J.E. Roemer (1986). For a critique of this tradition, see Roberts (1996). 6 For further treatments of these themes, consult the anthologies on Cohen's work (Kaufman, 2014; Sypnowich, 2006). Note also that recent anthologies collect published and unpublished texts by Cohen (2011; 2013a; 2014). 
about distributive justice and that we should understand this exchange as a more narrow contribution isolated from Cohen's other writings about distributive justice.

Accepting such a thesis is significant. If Miller is correct, we should not try to reconcile Cohen's different contributions into a coherent and positive contribution. Thus, little use would come of engaging in what Vrousalis has called a 'positive reconstruction' of the different elements in Cohen's work (2010, 186). This includes Vrousalis's $(2010,186)$ own argument for a broader, socialist connection in Cohen's work. Luck egalitarianism is often interpreted as being compatible with Cohen's broader socialist commitments. That might be why it is often discussed as an egalitarianism with special relevance for the political left (Callinicos, 2000; Kymlicka, 2002, 196-199; Vandenbroucke, 2001). ${ }^{7}$ If Cohen, as a socialist, did not consider luck egalitarianism an attractive view on distributive justice, perhaps this interpretation is misguided. Furthermore, affirming Miller's conclusions would effectively render pointless several attempts at broadening our understanding of luck egalitarianism by reconciling what Cohen writes in the exchange with Dworkin with what he writes elsewhere. If Miller is correct, then Cohen's other writings would be as likely a source for luck egalitarian inspiration as the works of any other writer. This conflicts with many ongoing developments in the luck egalitarian literature. Stemplowska (2013) has tried to relate Cohen's luck egalitarianism to his discussion of Nozick, while Olsaretti (2013) explores the relation between selfownership, community and luck egalitarianism. Smith (1998) discusses the connection between Cohen's critique of Rawls and Dworkin. This theme is also explored by Hurley $(2005,213)$, who thinks that there is tension between these elements in Cohen's thought. Our ability to reconcile the different elements is unimportant if they were never meant to be connected. Compatibility between them is accidental rather than deliberate. While such discussions implicitly deny Miller's claim, this paper is the first attempt to address it directly. The correctness of Miller's view is therefore not only relevant for those who take historical interest in what Cohen meant; it is a discussion of significant importance for how we are to discuss and develop luck egalitarianism. It is interesting how luck egalitarianism is often presented as something that springs from Dworkin's 1981 articles on Equality of Welfare and Equality of Resources (1981a; 1981b), along with replies published by Arneson (1989)

7 Cohen (1988; 1991; 1994; 1995a; 1999b; 2001b; 2004; 2009b) clearly thought his thinking to have such relevance. 
and Cohen (1989). The connection between these authors and the luck egalitarian tradition is becoming somewhat complex. ${ }^{8}$ Arneson (2000) explicitly abandoned luck egalitarianism in favor of what he calls 'luck prioritarianism', and Dworkin (2003) rejected the luck egalitarian label all along. Should we really remove Cohen from the list of canonical luck egalitarians? ${ }^{9}$

\section{Miller's Argument}

According to David Miller, we should conclude that luck egalitarianism did not reflect Cohen's own 'deepest convictions about justice and equality' (2014, 132). Despite the apparent consensus on Cohen's luck egalitarian credentials, Miller argues that luck egalitarianism did not 'represent Cohen's final, considered position on questions of justice' (2014, 134). Miller offers both an argument for his conclusion and an interpretation of how the apparent mislabelling came about. On the latter, he argues that:

Cohen became embroiled, initially by virtue of an exchange with Dworkin, in a debate about the metric of equality - the issue of the appropriate respect (resources or welfare or capabilities, etc.) in which people should be rendered equal as a matter of justice - and this spilled over into a further debate about the ways in which personal responsibility might justify inequality along one or other of these dimensions. (Miller, 2014, 132)

According to Miller, Cohen's apparent commitment to luck egalitarianism emerged from the now-famous exchange with Dworkin (Miller, 2014, 132). This exchange led Cohen to pursue the formulation of the best responsibilitysensitive version of distributive justice, luck egalitarianism. Miller points out, however, that this should not be confused with what Cohen believed to be the best formulation of egalitarianism, as such. The starting point of the CohenDworkin exchange on responsibility-sensitive egalitarianism is Dworkin's two 1981 articles presenting his position: equality of resources (1981a; 1981b). Cohen believes this position to be problematic in several ways: It ignores legitimate concerns for welfare disadvantages and its resistance towards compensating

8 Cohen self-identifies as a luck egalitarian on a number of occasions. In his 2004 text, 'Luck and Equality', Cohen self-identifies as a luck egalitarian when discussing 'the luck egalitarianism of Dworkin, Cohen and then young Arneson' $(2006,3)$. Cohen $(2008,7)$ repeats this classification in Rescuing Justice and Equality, where he reaffirms that he still believes in luck egalitarianism in a general way, and as Miller also notes identifies himself as a luck egalitarian along with Dworkin, Arneson and Roemer (G.A. Cohen, 2008, 310 fn51).

9 A list, which, if Miller is correct, grows thin. 
people for their preferences leads to the implausible rejection of compensation for those with unchosen, expensive tastes (G.A. Cohen, 1989). This exchange develops and stretches over a decade of replies, counter-replies and reflections (G.A. Cohen, 1993; 1999a; 2004; Dworkin, 2000; 2004). ${ }^{10}$ On Miller's account, we have come to misunderstand the point and purpose of this particular debate as well as Cohen's reason for engaging in it. ${ }^{11}$ Rather than a debate over the correct view on egalitarianism, we should understand it as Cohen's contribution to a debate over the best responsibility-sensitive egalitarianism (Miller, 2014, 133). Cohen's argument against Dworkin, thus interpreted, is that luck egalitarianism is preferable to Dworkin's equality of resources as an account of responsibility-sensitive egalitarianism. But this is compatible with the thought that Cohen's considered belief regarding egalitarianism was not a luck egalitarian one.

Miller thus forwards a narrower interpretation of what is at stake in the Dworkin exchange, offering textual evidence for the plausibility of this view. The first is Cohen's much-quoted claim that 'Dworkin has, in effect, performed for egalitarianism the considerable service of incorporating within it the most powerful idea in the arsenal of the antiegalitarian right: the idea of choice and responsibility' (G.A. Cohen, 1989, 933). According to Miller, this supports his interpretation of the Dworkin exchange as having a more limited role in Cohen's writings. Why else, Miller wonders, would one consider it a service to egalitarianism 'to incorporate within it the strongest idea of its opponents, rather than a retreat or a capitulation?' (2014, 132). Miller argues we can either take Cohen to suggest that the best way to do philosophy is to seek out compromises between different values such as responsibility and equality. ${ }^{12}$ Or we can understand the Cohen-Dworkin exchange to be narrower; that is, to be about how best to incorporate responsibility into egalitarianism. In defence of the latter interpretation, Miller submits that the thought that philosophy should seek out such compromises is very far from how Cohen describes the purpose of philosophy.

10 For important recent contributions to the debate over expensive tastes and distributive justice, see Hansen and Midtgaard (2011), Knight (2009a), Lippert-Rasmussen (2013) and Quong (2006).

11 According to Levy, Cohen once said he had been engaged in 'three long-running arguments over the course of my career. The first was with the Althusserians, on Marx's theory of history, and I knew what that was about. The second was with Nozick, on self-ownership, and I knew what that was about. The third was with Dworkin, on expensive tastes, and I still have no idea what that was about' (Levy, 2010). That may suggest that the rest of us could be forgiven for making the mistake Miller attributes to us regarding the purpose and content of the Dworkin exchange.

12 Cohen and Miller famously disagree about this in a very fundamental way (G.A. Cohen, 2003; 2008; Miller, 2008). 
Cohen's modus operandi is to search for the correct principle as opposed to the best compromise. Interestingly, Miller suggests - but quickly rejects - a third interpretation, that 'Cohen might have thought that choice and responsibility were important ideas irrespective of whether they were championed by the right or the left' (2014, 133). Given that the disagreement concerns whether Cohen is a luck egalitarian, it would seem as though the very issue at stake here is whether (according to Cohen) choice and responsibility are important to egalitarians. The third of these interpretations cannot be ruled out as quickly as Miller does.

Miller offers further textual evidence for disagreeing with the mainstream interpretation of Cohen's view on distributive justice. He points to Cohen's discussion in Why Not Socialism?, where Cohen (2001b; 2009b) considers whether there are inequalities that are allowed by a luck egalitarian principle but which are nevertheless problematic. In this discussion, Cohen describes how large inequalities, even those reflecting people's exercises of responsibility, can be bad because they undermine community (G.A. Cohen, 2009b, 38-39). Miller (2014, 134-135) submits that such doubts should be taken to support the notion that luck egalitarianism is not Cohen's considered position on distributive justice. He proceeds to point out further that such doubts can also be identified in another late article by Cohen, 'Fairness and Legitimacy in Justice, And: Does Option Luck Ever Preserve Justice?' (2009a). Based on quotes from 'Back to Socialist Basics' (G.A. Cohen, 1994, 11), Miller argues that it may be more appropriate to consider Cohen's views to be in line with Marx' famous slogan 'from each according to his ability to each according to his needs' $(2014,147) .{ }^{13}$

Summing up, Miller argues that the position on distributive justice (which Cohen defends in the Cohen-Dworkin exchange), the responsibility-sensitive theory now known as luck egalitarianism, is not his own considered view on egalitarian distributive justice. In the exchange with Dworkin, Cohen attempted to formulate the best responsibility-sensitive view, but the exchange and the arguments put forward in it do not reflect anything more than this and do not have importance beyond this limited purpose. ${ }^{14}$ The next section argues that Miller's argument fails.

13 Whether Marx thought this to be a principle of distributive justice is unimportant for this discussion, even though it is a source of continued discussion (Lukes, 1988; Wood, 2004). Cohen (1995b, 195) held the view that Marx did in fact consider capitalism unjust.

14 Reflecting on his argument that Cohen is not to be considered a luck egalitarian, Miller puts forth a further point: If Cohen is not a luck egalitarian, this is not a reason to be disheartened. Miller submits one reason in particular for this: that luck egalitarianism is ill-equipped to deal with other-affecting choices. This particular discussion is not addressed here but the thought has received some attention recently (Elford, 2013; Lazenby, 2009; Lippert-Rasmussen, 2015). 


\section{Luck egalitarianism as a recurrent feature in Cohen's thinking}

This section sets out to argue against Miller's claim that Cohen's considered belief on distributive justice is not luck egalitarian. Two different lines of reasoning are employed here, each of which draws extensively on Cohen's writings. The first considers the status of the Dworkin exchange and what is at stake there. It is argued that Cohen often writes in the Dworkin exchange of how this pertains to the correct view on egalitarian justice rather than merely the best formulation of responsibility-sensitive egalitarianism. Further along these lines, it is pointed out how Cohen elsewhere refers to the Dworkin exchange as a statement of something more fundamental regarding egalitarianism. The second argument brings forth instances where Cohen expresses views on distributive justice that are luck egalitarian or he assesses distributions or distributive principles from a luck egalitarian perspective, thereby pointing out where Cohen uses luck egalitarianism as a yardstick to assess distributions and distributive principles in contexts unconnected to the Dworkin exchange. This is important, because if Cohen evokes luck egalitarianism to assess both distributions and distributive principles, then he must have meant it to be something more than a principle better than Dworkin's. Based on the textual argument, Miller's conclusion is rejected. The final part of the section reflects briefly on Miller's claim that Cohen would instead have opted for the Marxian ideal of 'from each according to his ability to each according to his needs'. This reflection also concerns the pluralism of Cohen's thought; that is, the relation between distributive justice and other values in his thought.

Cohen suggests on several occasions that the exchange with Dworkin is important beyond the exchange itself. From within the Dworkin exchange, we can identify a number of references in which Cohen expressed its importance. ${ }^{15}$ In 'On the Currency of Egalitarian Justice', addressing Dworkin, Cohen presents their exchange as a discussion of egalitarianism as such. There are no qualifications about this being only about responsibility-sensitive egalitarianism to support Miller's thesis. On the contrary, in the methodological preliminaries, Cohen states that the debate is about 'the primary egalitarian impulse' and 'the fundamental egalitarian aim' $(1989,908)$. Cohen also stresses how the discussions and objections considered are 'egalitarian objections' (1989, 912). This suggests, against Miller's thesis, that Cohen himself believes this debate to be about

15 I consider the following texts as the prime contributions to the debate with Dworkin: (G.A. Cohen, 1989; 1993; 2004; 2006). 
egalitarianism as such, rather than the more narrow debate about responsibilitysensitive egalitarianism. Later, Cohen reflects on what is at stake in the exchange. Addressing those who would find their debate over expensive tastes somewhat curious, perhaps because they do not want to live in a society where the state seeks to correct such inequalities, Cohen clarifies that when he considers some feature of a distribution $(\mathrm{x})$ an injustice, this 'will not mean " $\mathrm{x}$ represents an injustice that ought to be rectified by the state"' but rather it will mean 'that the world is less than fully just by virtue of the presence of $\mathrm{x}$ in it'. Furthermore, he states that when he writes "compensation is required by egalitarian justice," I mean: for there to be egalitarian distributive justice, there must be compensation' (G.A. Cohen, 2004, 4). Again, the disagreement is presented as something fundamental: egalitarian justice. Similarly, Cohen explicitly states in 'Expensive Taste Rides Again' that the disagreement is about 'the ultimate principle of justice' (2004, 22). In the same text, Cohen maintains that the Dworkin exchange 'raises questions at the heart of the theory of justice' (2004, 7). Reflecting over the exchange with Dworkin, Cohen flatly rejects the notion that equality is compromised by the attention to personal responsibility. Rather, he argues in 'Luck and Equality' that 'an egalitarianism that is sensitive to issues of responsibility is demanded by a proper understanding of the ideal of equality itself: it is not a development that represents a compromise with the ideal of equality' (G.A. Cohen, 2006, 443). The above clearly indicates that, in his exchange with Dworkin, Cohen thinks that much more is at stake than Miller suggests. Rather than a debate about the strengths and weakness of Dworkin's distributive ideal, this is a debate about egalitarianism as such. Thus, Cohen himself does not consider the Dworkin exchange to be an argument about the best responsibility-sensitive theory of distributive justice but rather about the correct view on egalitarian distributive justice.

That the Dworkin exchange reflects Cohen's view about distributive justice is also the impression we get from how Cohen refers to this exchange elsewhere. In his 1994 text 'Back to Socialist Basics', Cohen briefly suggests a principle of equality which 'says that the amount of amenity and burden in one person's life should be roughly comparable to that in any other's' (1994, 11). He then notes that for a more precise definition of the principle of equality, we should consult his 'Currency' text (n16 G.A. Cohen, 1994, 11). ${ }^{16}$ In Self-ownership, Freedom and Equality, Cohen refers to the same article as discussing equality as such (1995b, 25 n12). In Rescuing Justice and Equality, Cohen stresses how his critique of incentive pay to the talented follows from the position presented in the Dworkin exchange (2008, 403-404). A collection of Cohen's essays has been published

16 He makes a similar reference in 'Expensive Tastes and Multiculturalism' (G.A. Cohen, 1999a, 81). 
posthumously, including a number of already published works. Interestingly, however, it also includes a text which Cohen considered to publish as an afterword to the book Self-ownership, Freedom and Equality. This text discusses many issues that came up in the discussion with Dworkin, once again underscoring how Cohen (2011, 61-72) himself thought the discussions to be connected. Thus, considerable evidence supports the suggestion that Cohen himself did not consider his exchange with Dworkin as an isolated, narrow exchange in the sense suggested by Miller. We see this in how Cohen describes what is at stake while conducting the exchange as well as how he refers to it in his other works. This suggests that Cohen did not consider the Dworkin exchange as isolated from his political philosophy as a whole.

The textual evidence weighing against Miller's claim goes further. The next section brings forth examples from Cohen's writings where he formulates his view on justice in accordance with these luck egalitarian principles. Such commitments are overwhelmingly present in the Dworkin discussion (G.A. Cohen, 1993, 28; 2004, 8, 14, 22), but interestingly they can also be found spread throughout Cohen's work in general. In 'Back to Socialist Basics', Cohen critically discusses the distributive principles presented in the Commission on Social Justice's report. ${ }^{17}$ In assessing the distributive principles put forward in the report, Cohen (1994, 12) proceeds from a luck egalitarian position, denying compensation for inborn talents and fortunate social circumstances but allowing, in principle, for effort to be rewarded $(1994,13) .{ }^{18}$ In 'Is Socialism Inseparable from Common Ownership?', Cohen (1995a) discusses the Labour Party leadership's (eventually successful) attempt to abolish the party's commitment to common ownership. ${ }^{19}$ Cohen denounces the societal division between capital and labour associated with the private ownership of capital on the basis that it conflicts with the egalitarian ideal that we should strive for 'access to what's valuable in life for everyone, on equal terms, whatever may be their social or geographical or ethnic origin, their gender, their talents and their tastes' (1995a, 1). The luck egalitarian commitment to correct differences from differential circumstances looms large over such a sentence. In the same vein Cohen notes that the needs of people who are unable to work due to bad circumstances should not be ignored, as they would be in an orthodox interpretation of giving people the full fruit of their labor (G. A. Cohen, 1995a, p. 2). Addressing disagreements within Labour regarding New Labour's view on equal opportunity, Cohen shows how a consistent view on

17 A commission initiated by Labour in the early 1990s (Commission on Social Justice, 1994). 18 Though acknowledging how hard it may be to distinguish from inborn talent.

19 In fairness, it should be noted that Cohen criticizes the original clause IV for being inattentive to differences in need; in so doing, Cohen utilizes the Marxian slogan. 
equality of opportunity, demands much more redistribution than the Labour leadership allows for (Cohen, 1999b, 358). The luck egalitarianism nature of this position is quite clear from the text. Not least, when Cohen distinguishes his egalitarianism from the 'mechanic equality' dismissed by New Labour: 'Is equality desirable? It is indeed undesirable when it is so construed that it contradicts socialist equality of opportunity, when, for example, it demands equal income regardless of different preferences about work and life-style' (Cohen, 1999b, 357). ${ }^{20}$ Indeed Cohen stresses in a clearly luck egalitarian fashion, people who make different choices for which they are responsible, are not unequal in any problematic sense.

Later Cohen repeats this luck egalitarian critique of capitalist ownership (1995b, 199). In Self-ownership, Freedom and Equality, as a luck egalitarian, Cohen briefly mentions his objection to Nozick's principle of self-ownership and that it allows how people fare to be determined by bad brute luck. The self-ownership principle does so because "no luck is bruter than that of how one is born, raised and circumstanced, the good and bad results of which adhere firmly to individuals under the self-ownership principle' (G.A. Cohen, 1995b, 229). In his critique of Rawls, Cohen $(2008,100)$ holds very firmly that we should deny compensation to those who are talented but do not put in more effort than others. Importantly, he qualifies this view by allowing compensation for labor burdens (G.A. Cohen, 2008, 102-103). Reflecting on this discussion, the luck egalitarian ideals are once again put forward; here, designated as his root beliefs:

My root belief is that there is injustice in distribution when inequality of goods reflect not such things as differences in the arduousness of different people's labours, or people's different preferences and choices with respect to income and leisure, but myriads of lucky and unlucky circumstances. (G.A. Cohen, 2008, 126) ${ }^{21}$

In Why Not Socialism?, his final book, Cohen discusses a camping trip and intuitive reactions to various claims for receiving more than others. He denies reward to the talented who do not work harder than others, to those who are lucky in external resources, and to those arguing that we should depart from equality due to their inherited privileges (G.A. Cohen, 2009b, 7-9). ${ }^{22}$ From there,

20 Whether luck egalitarians can consider equalities unjust has been a contested topic among luck egalitarians. For the argument that they cannot, see (Segall, 2010, 2011, 2013). For the argument that inequalities can be unjust, see (Albertsen and Midgaard, 2014).

21 A formulation that is also found in the version of the text printed in G.A. Cohen (2001a, 131). 22 From the first publication of the essay in 2011 until its publication as a book in 2009, there is a small but noteworthy shift in how Cohen adds the concern for allowing talented persons to receive higher salaries; compare G.A. Cohen (2001b, 60; 2009b, 8). 
Cohen proceeds to defend a distributive principle called socialist equality of opportunity, which 'seeks to correct for all unchosen disadvantages, disadvantages, that is, for which the agent cannot herself reasonably be held responsible' (2009b, 18). ${ }^{23}$ He argues that when this distributive principle prevails, 'differences of outcome reflect nothing but differences in choice and taste, not differences in natural and social capacities and powers' (G.A. Cohen, 2009b, 18). These are clear luck egalitarian statements and, again, one used to evaluate distributive principles in a context much different from the Dworkin debate. ${ }^{24}$

Had Cohen not believed luck egalitarianism to be the correct view on distributive justice; that is, had he not held it as his considered belief, as Miller argues to be the case, then why would he a) point to these discussions as statements regarding what he believes about equality, and b) use luck egalitarianism as a distributive yardstick for assessing a number of distributive principles and distributions? From the above, we can learn two important lessons regarding Cohen's egalitarianism. One is that, in many places in his writings, Cohen makes statements to the effect that he believed that his exchange with Dworkin says something about egalitarianism as such. The other is that we can identify the luck egalitarian commitments in many places, not only as references to the text discussing responsibility-sensitive egalitarianism but also as independent yardsticks, which Cohen uses to evaluate other distributive principles and distributions. Both of these observations contradict Miller's claim that calling Cohen a luck egalitarian is mistaken and that the luck egalitarianism credited to him is confined to the Dworkin exchange.

What should we make of Miller's claim that Cohen would instead have endorsed the Marxian slogan, 'from each according to his ability, to each according to his needs'? Cohen reflected on Marx' slogan on several occasions (1995b; 2001a). ${ }^{25}$ Regarding the Marxian distributive ideal, Cohen holds the view that it is

23 A principle he also defends in the earlier version of the essay (G.A. Cohen, 2001b, 61) as well as in his 'Socialism and Equality of Opportunity' (G.A. Cohen, 1999b).

24 One could add more indirect affirmations of the luck egalitarian principle, but the ones mentioned above should be taken to be more important than those. Other examples of more marginal luck egalitarian statements include G.A. Cohen (2001b, 76 n11; 2009a, 15, 20 n20; 2011, 234).

25 It also appears as though Cohen planned to write a book with that very title. In 'Expensive Tastes and Multiculturalism', it is stated that a longer version of the text appears in Cohen's 'From Each According to His Ability, to Each According to His Needs, Cambridge, 1997' (G.A. Cohen, 1999a, 80). A book with that title was never published. I suspect - but have been unable to confirm - that this is an early title for what became Cohen's book published by Cambridge, Self-ownership, Freedom and Equality (G.A. Cohen, 1995b). The publication dates may be due to a delay of the publication of the 1999 anthology. 
connected to the Marxian optimism regarding the abundance of material wealth in the future communist society; an optimism which, according to Cohen, led Marx to believe that it was unnecessary to discuss distributive questions further (G.A. Cohen, 1995b, 11, 126; 2001a, 103). Cohen does, however, critically reflect over the ideal at different points. In Rescuing Justice, Cohen (2008, 225) remarks that he has 'some sympathy' for the slogan but also expresses further doubts about it. Cohen's further doubt regarding the slogan is that it places no limit on how much can be expected of the talented and was 'at best poorly formulated' (2008, 208-209). As Cohen considers justice to include a person's prerogative, denying that we are to be 'slaves of social justice' $(2008,10)$, this consequence of the slogan is considered bad on Cohen's account (2008, 62 n34). Furthermore, when Cohen remarks positively on the slogan, for example on the anti-market tenants inherently in it, he does so also for luck egalitarian reasons that the market rewards underserved talents, and punishes people's circumstances: 'You do not get more because you produce more, and you do not get less because you are not good at producing $(1994,11) .{ }^{26}$ Cohen's relationship to the Marxian ideal is apparently rather lukewarm, and it remains important that he assesses it as failing from a luck egalitarian distributive standpoint.

The final issue to address is how Cohen could both criticize the distributions that luck egalitarianism endorses and hold luck egalitarianism as his considered beliefs about egalitarian justice. Cohen engages on several occasions with the distinction between option luck and brute luck, and does express doubts regarding the extent to which it captures distributive justice. In 'Expensive Tastes Ride Again', Cohen argues that there are some chosen preferences, where people should be compensated if they are disadvantaged by having these preferences (Cohen, 2004). The preferences in question are those which reflect people's deepest values, their judgemental tastes (Cohen, 2004, 10). While such explorations can be considered explorations of where to best draw the line between what people are considered responsible for (Knight, 2009a), Cohen came even closer to challenging the distinction as such on another occasion. In the text 'Fairness and Legitimacy in Justice, And: Does Option Luck Ever Preserve Justice?' Cohen discusses whether option luck is able to preserve the distributive justice present in an initial situation of equality, as opposed to only the legitimacy of the new distribution (Cohen, 2009a). ${ }^{27}$ We have reasons to believe that Cohen was not entirely convinced by the conclusion. He remarks that his piece is 'inconclusive, and also unconcluding' (Cohen, 2009a, 19). Furthermore, in 'Why Not Socialism' option luck retains the ability to render

26 Miller cites this, but does not reflect over a possible luck egalitarian interpretation of it.

27 For two prominent arguments for why Cohen's argument is not successful, see (Butt, 2012; Williams, 2013). For further discussion, see (Elford, 2016) 
unequal distributions just (Cohen, 2009b). In his discussion of this topic, Williams points out that whether option luck preserves the justice in an initial equality depends on what it was that made this initial equality just (Williams, 2013, 80). If it was its specific pattern, then this verdict is correct, but if it was rather it being in accordance with some responsibility-sensitive principle, then the new distribution may be just in the same way as the initial equality (as opposed to merely legitimate). Notwithstanding the strengths of the argument Cohen puts forward in the text, Miller is correct in observing that they indicate that he distances himself somewhat from luck egalitarianism.

Most of the criticism and reservations Miller highlights are not to be taken as doubts that Cohen has regarding luck egalitarianism. Rather, we should consider them manifestations of his pluralism. Throughout his work, Cohen writes that other issues matter besides distributive justice (1989, 906; 1994, 11; 1995b, 31; 2004, 13; 2008, 354). His hesitation towards some distributions that luck egalitarian distributive justice allows for is not of a distributive justice kind but rather a concern for how they affect community. While Miller (2014, 150) acknowledges Cohen's pluralism, he seems not to be attentive enough to the importance of this for the discussion at hand. The pluralism in Cohen's thought makes it entirely possible that community and equality are two different values that we must weigh up against each other. Cohen notes in this context that even though we cannot forbid such inequalities in the name of distributive justice they 'should nevertheless be forbidden, in the name of community' (Cohen, 2009b, 37). The focus on community is not according to Cohen, required by equality but still a prerequisite for 'human relations to take a desirable form' (Cohen, 2009b, 39). That Cohen acknowledges this makes him no less a luck egalitarian; it merely makes him a pluralist, as luck egalitarians often happen to be. A very clear statement of the relationship between distributive justice and other values is found in Rescuing Justice and Equality. There Cohen writes that in the pursuit of equality it can be bad policy to seek to promote justice, whether because that would not in fact promote justice, or because seeking to promote it would prejudice other values' (Cohen, 2008, 381). The pursuit of justice must thus be weighed against other values as well in a pluralist fashion.

\section{Conclusion}

The late G.A. Cohen is routinely considered one of the founding fathers of luck egalitarianism, an influential theory of distributive justice. David Miller's argument that Cohen's considered belief concerning distributive justice is not luck 
egalitarian and that we should understand the Cohen-Dworkin exchange in a much narrower way is ultimately unconvincing. Cohen clearly considers the exchange with Dworkin to be about egalitarianism as such, rather than about the best responsibility-sensitive version of egalitarianism. Furthermore, Cohen often offers luck egalitarian formulations of his own view outside the exchange with Dworkin and uses luck egalitarianism as an independent yardstick to evaluate principles and distributions. For these reasons we should indeed believe Cohen's considered view about distributive justice to be a luck egalitarian view.

Acknowledgements: This paper has benefitted from discussions with Søren Flinch Midtgaard and Jens Damgaard Thaysen. It also benefitted from comments from the two anonymous reviewers. Part of this paper was written while funded by the Carlsberg Foundation (Grant No. CF14-0896).

\section{References}

Albertsen, Andreas, and Sören Flinch Midtgaard. 2014. "Unjust Equalities.” Ethical Theory and Moral Practice 17(2): 335-46.

Arneson, Richard J. 1989. "Equality and Equal Opportunity for Welfare." Philosophical Studies 56(1): 77-93.

Arneson, Richard J. 2000. "Luck Egalitarianism and Prioritarianism.” Ethics 110: 339-49.

Arneson, Richard J. 2011. "Luck Egalitarianism - A Primer.” In Responsibility and Distributive Justice, eds. Carl Knight and Zofia Stemplowska. Oxford, Oxford University Press, 24-50.

Butt, Daniel. 2012. "Option Luck, Gambling, and Fairness.” Ethical perspectives 19(3): 417-43. Callinicos, Alex. 2000. Equality. Cambridge, Blackwell Publishers.

Cohen, G. A. 1978. Karl Marx's Theory of History: A Defence. Oxford, Oxford University Press.

Cohen, G. A. 1988. History, Labour, and Freedom: Themes from Marx. Oxford, Oxford University Press.

Cohen, G. A. 1989. “On the Currency of Egalitarian Justice.” Ethics 99(4): 906-44.

Cohen, G. A. 1991. The Future of Disillusion. Toronto, Faculty of Law, University of Toronto.

Cohen, G. A. 1993. "Equality of What? On Welfare, Goods and Capabilities." In The Quality of Life, eds. Martha Nussbaum and Amartya Sen. Oxford, Oxford University Press, 9-29.

Cohen, G. A. 1994. "Back to Socialist Basics." New Left Review 201: 3-16.

Cohen, G. A. 1995a. Is Socialism Inseparable from Common Ownership? Nottingham, Spokesman.

Cohen, G. A. 1995b. Self-Ownership, Freedom, and Equality. Cambridge, Cambridge University Press.

Cohen, G. A. 1999a. “Expensive Tastes and Multiculturalism.” In Multiculturalism, Liberalism, and Democracy, eds. Rajeev Bhargava, Amiya Kumar Bagchi, and R. Sudarshan. New Delhi, Oxford University Press, 80-100.

Cohen, G. A. 1999b. "Socialism and Equality of Opportunity." In Political Thought, eds. Michael Rosen, Jonathan Wolff, and Catriona McKinnon. Oxford, Oxford University Press. 
Cohen, G. A. 2000. Karl Marx's Theory of History: A Defence. Oxford, Oxford University Press. Cohen, G. A. 2001a. If You're an Egalitarian, How Come You're So Rich? Cambridge, Harvard University Press.

Cohen, G. A. 2001b. “Why Not Socialism?” In Democratic Equality: What Went Wrong?, ed. Ed Broadbent. Toronto, University of Toronto Press, 58-78.

Cohen, G. A. 2004. "Expensive Tastes Ride Again.” In Dworkin and His Critics: With Replies by Dworkin, ed. Justine Burley. Oxford, Blackwell, 3-29.

Cohen, G. A. 2006. "Luck and Equality." Philosophy and Phenomenological Research 72(2): 439-46.

Cohen, G. A. 2008. Rescuing Justice and Equality. Cambridge, Harvard University Press.

Cohen, G. A. 2009a. "Fairness and Legitimacy in Justice, And: Does Option Luck Ever Preserve Justice?." In Hillel Steiner and the Anatomy of Justice: Themes and Challenges, eds. Stephen de Wijze, Matthew H. Kramer, and lan Carter. New York, Routledge, 3-21.

Cohen, G. A. 2009a. "Fairness and Legitimacy in Justice, And: Does Option Luck Ever Preserve Justice?." In Hillel Steiner and the Anatomy of Justice: Themes and Challenges, eds. Stephen de Wijze, Matthew H. Kramer, and lan Carter. New York, Routledge, 3-21.

Cohen, G. A. 2009b. Why Not Socialism? Princeton, Princeton University Press.

Cohen, Gerald A. 2003. "Facts and Principles." Philosophy \& Public Affairs 31(3): 211-45.

Cohen, Gerald A. 2011. On the Currency of Egalitarian Justice, and Other Essays in Political Philosophy. ed. Michael Otsuka. Princeton, Princeton University Press.

Cohen, Gerald A. 2013a. Finding Oneself in the Other. Princeton, Princeton University Press.

Cohen, Gerald A. 2013b. “Isaiah's Marx, and Mine.” In Finding Oneself in the Other, ed. Michael Otsuka. Princeton, Princeton University Press, 1-16.

Cohen, Gerald A. 2014. Lectures on the History of Moral and Political Philosophy. Princeton, Princeton University Press.

Commission on Social Justice, ed. 1994. Social Justice: Strategies for National Renewal: The Report of the Commission on Social Justice. London, Vintage.

Dworkin, Ronald. 1981a. "What Is Equality? Part 1: Equality of Welfare.” Philosophy \& Public Affairs 10(3): 185-246.

Dworkin, Ronald. 1981b. “What Is Equality? Part 2: Equality of Resources.” Philosophy \& Public Affairs 10(4): 283-345.

Dworkin, Ronald. 2000. Sovereign Virtue : The Theory and Practice of Equality. Cambridge, Harvard Univ. Press.

Dworkin, Ronald. 2003. “Equality, Luck and Hierarchy." Philosophy \& Public Affairs 31(2): 190-98.

Dworkin, Ronald. 2004. "Ronald Dworkin Replies." In Dworkin and His Critics: With Replies by Dworkin, ed. Justine Burley. Oxford, Blackwell, 339-95.

Elford, Gideon. 2013. "Equality of Opportunity and Other-Affecting Choice: Why Luck Egalitarianism Does Not Require Brute Luck Equality." Ethical Theory and Moral Practice 16(1): 139-49.

Elford, Gideon. 2016. "Preserving Fairness: Williams against Cohen on Just Inequality." Critical Review of International Social and Political Philosophy 19(6): 699-713.

Hansen, Rasmus Sommer, and SøRen Flinch Midtgaard. 2011. "Sinking Cohen's Flagship - or Why People with Expensive Tastes Should Not Be Compensated." Journal of Applied Philosophy 28(4): 341-54.

Heath, Joseph. 2008. "Political Egalitarianism." Social Theory \& Practice 34(4): 485-516.

Hurley, Susan. 2005. Justice, Luck, and Knowledge. Cambridge, Harvard University Press. 
Kaufman, Alexander, ed. 2014. Distributive Justice and Access to Advantage: G. A. Cohen's Egalitarianism. Cambridge, Cambridge University Press.

Knight, Carl. 2009a. "Egalitarian Justice and Valuational Judgment." Journal of Moral Philosophy 6(4): 482-98.

Knight, Carl. 2009b. Luck Egalitarianism. Edinburgh, Edinburgh University Press.

Knight, Carl. 2013. "Luck Egalitarianism.” Philosophy Compass 8(10): 924-34.

Knight, Carl, and Zofia Stemplowska. 2011. "Responsibility and Distributive Justice: An Introduction." In Responsibility and Distributive Justice, eds. Carl Knight and Zofia Stemplowska. Oxford, Oxford University Press, 1-23.

Kymlicka, Will. 2002. Contemporary Political Philosophy: An Introduction. 2nd ed. New York, Oxford University Press.

Lazenby, Hugh. 2009. "One Kiss Too Many? Giving, Luck Egalitarianism and Other-Affecting Choice." Journal of Political Philosophy: 271-86.

Levy, J. T. 2010. "Book in Review: Rescuing Justice and Equality, by G. A. Cohen. Cambridge, Harvard University Press, 2008. 448 Pp. \$45.00.” Political Theory 38(4): 593-96.

Lippert-Rasmussen, Kasper. 2001. “Egalitarianism, Option Luck, and Responsibility.” Ethics 111 (3): 548-79.

Lippert-Rasmussen, Kasper. 2009. “Justice and Bad Luck” ed. Edward N. Zalta. The Stanford Encyclopedia of Philosophy Fall 2009. http://plato.stanford.edu/archives/fall2009/ entries/justice-bad-luck/.

Lippert-Rasmussen, Kasper. 2013. "Offensive Preferences, Snobbish Tastes, and Egalitarian Justice: Offensiveness, Snobbishness, and Egalitarian Justice.” Journal of Social Philosophy 44(4): 439-58.

Lippert-Rasmussen, Kasper. 2016. Luck Egalitarianism. London, Bloomsbury. Lukes, Steven. 1988. Marxism and Morality. New York, Oxford University Press.

Miller, David. 2008. "Political Philosophy for Earthlings." In Political Theory: Methods and Approaches, eds. David Leopold and Marc Stears. Oxford, Oxford University Press, 29-48.

Miller, David. 2014. "The Incoherence of Luck Egalitarianism." In Distributive Justice and Access to Advantage: G. A. Cohen's Egalitarianism, ed. Alexander Kaufman. Cambridge, Cambridge University Press, 131-50.

Olsaretti, Serena. 2013. "Rescuing Justice and Equality from Libertarianism." Economics and Philosophy 29(01): 43-63.

Quong, Jonathan. 2006. "Cultural Exemptions, Expensive Tastes, and Equal Opportunities.” Journal of Applied Philosophy 23(1): 53-71.

Roberts, Marcus. 1996. Analytical Marxism: A Critique. London, Verso.

Roemer, John E., ed. 1986. Analytical Marxism. Cambridge, Cambridge University Press.

Roemer, John E. 1993. "A Pragmatic Theory of Responsibility for the Egalitarian Planner." Philosophy and Public Affairs 22(2): 146-66.

Roemer, John E. 1995. “Equality and Responsibility.” Boston Review 20(2). http://bostonreview. net/BR20.2/roemer.html (November 23, 2011).

Roemer, John E. 1996a. Egalitarian Perspectives: Essays in Philosophical Economics. New York, Cambridge University Press.

Roemer, John E. 1996b. Theories of Distributive Justice. Cambridge, Harvard University Press. Segall, Shlomi. 2007. "In Solidarity with the Imprudent: A Defense of Luck Egalitarianism." Social Theory and Practice 33(2): 177-98.

Segall, Shlomi. 2010. Health, Luck, and Justice. Princeton, Princeton University Press.

Segall, Shlomi. 2013. Equality and Opportunity. Oxford, Oxford University Press. 
Smith, Paul. 1998. “Incentives and Justice: G.A. Cohen's Egalitarian Critique of Rawls.” Social Theory \& Practice 24(2): 205-35.

Stemplowska, Zofia. 2013. "Luck Egalitarianism.” In The Routledge Companion to Social and Political Philosophy, eds. Gerald F Gaus and Fred D’Agostino. New York, Routledge, 389-400.

Sypnowich, Christine, ed. 2006. The Egalitarian Conscience: Essays in Honour of G.A. Cohen. New York, Oxford University Press.

Temkin, Larry. 1993. Inequality. New York, Oxford University Press.

Temkin, Larry. 2011. “Justice, Equality, Fairness, Desert, Rights, Free Will, Responsibility and Luck." In Responsibility and Distributive Justice, eds. Carl Knight and Zofia Stemplowska. New York, Oxford University Press, 51-76.

Temkin, Larry. 2013. "Inequalities and Health.” In Inequalities in Health: Concepts, Measures, and Ethics, Population-level bioethics series, eds. Nir Eyal, Samia Hurst, Ole Frithjof Norheim, and Daniel Wikler. Oxford, Oxford University Press, 13-26.

Temkin, Larry S. 1986. “Inequality." Philosophy \& Public Affairs 15(2): 99-121.

Thaysen, Jens Damgaard, and Andreas Albertsen. 2017. "When Bad Things Happen to Good People: Luck Egalitarianism and Costly Rescues." Politics, Philosophy \& Economics 16(1): 93-112.

Vandenbroucke, Frank. 2001. Social Justice and Individual Ethics in an Open Society : Equality, Responsibility, and Incentives. Berlin, Springer.

Vrousalis, Nicholas. 2010. "G. A. Cohen's Vision of Socialism." The Journal of Ethics 14(3-4): 185-216.

Williams, Andrew. 2013. "How Gifts and Gambles Preserve Justice." Economics and Philosophy 29(01): 65-85.

Wood, Allen W. 2004. Karl Marx. 2nd ed. New York, Routledge. 
Reproduced with permission of copyright owner. Further

reproduction prohibited without permission. 